\title{
Do Stock Markets Play a Role in Determining the COVID-19 Economic Stimulus? A Cross-Country Analysis
}

\author{
Muhammad Shafiullah \\ School of Economics, University of Nottingham Malaysia \\ Jalan Broga, 43500 Semenyih, Selangor, Malaysia \\ Email: Muhammad.Shafiullah@nottingham.edu.my

\section{Usman Khalid ${ }^{1}$} \\ Department of Innovation in Government \& Society, \\ College of Business and Economics, United Arab Emirates University \\ Email: usman.khalid@uaeu.ac.ae \\ Sajid M. Chaudhry \\ Economics, Finance \& Entrepreneurship Group \\ Aston Business School, Aston University, United Kingdom \\ Email: s.chaudhry9@aston.ac.uk
}

Declarations of interest: none

${ }^{1}$ Corresponding author.

This article has been accepted for publication and undergone full peer review but has not been through the copyediting, typesetting, pagination and proofreading process, which may lead to differences between this version and the Version of Record. Please cite this article as doi: 10.1111/TWEC.13130

This article is protected by copyright. All rights reserved 
DR. MUHAMMAD SHAFIULLAH (Orcid ID : 0000-0003-3325-080X)

DR. USMAN KHALID (Orcid ID : 0000-0001-9879-6948)

Article type : Original Article

Corresponding author mail id : usman.khalid@uaeu.ac.ae

\title{
Do Stock Markets Play a Role in Determining COVID-19 Economic Stimulus?
}

\section{A Cross-Country Analysis}

\begin{abstract}
This paper makes an innovative contribution to the extant literature by analyzing the determinants of economic stimulus packages implemented by governments in response to the COVID-19 pandemic. In particular, we explore whether stock market declines observed in many countries can predict the size of COVID-19 stimulus packages. Moreover, we explore whether a country's level of income can augment the underlying relationship between stock market declines and stimulus packages. The findings reveal that a larger stock market decline results in a larger stimulus package; however, this effect is only observed in countries that have an income level greater than the mean and/or median per capita gross domestic product (GDP). Moreover, our results show that monetary policy is more responsive to a stock market decline than fiscal policy. Thus, our results underscore the importance of international donor agencies such as the World Bank and International Monetary Fund (IMF) in supporting less affluent countries in coping with the adverse impacts of the COVID-19 pandemic on their economies.
\end{abstract}


Keywords: Coronavirus 2019 (COVID-19); COVID-19 pandemic; economic stimulus; stock market decline.

JEL Classifications: E44; E62; G01; H12

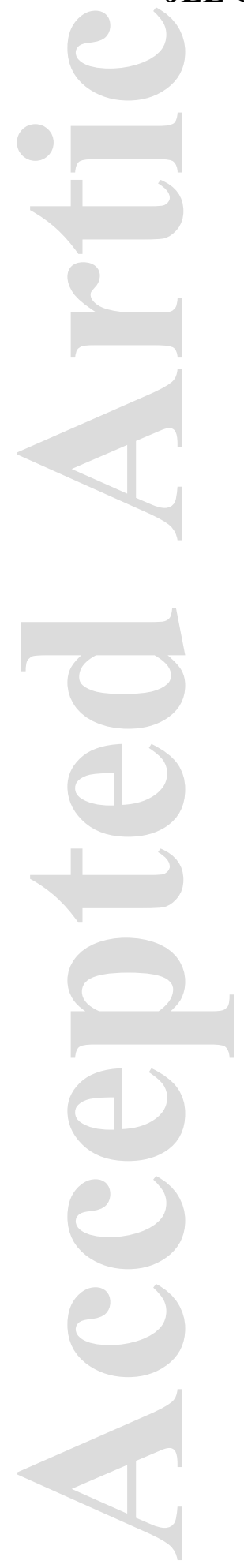

This article is protected by copyright. All rights reserved 


\section{$1 \quad$ Introduction}

Since mid-February 2020, the spread of COVID-19 rattled economic prospects and financial markets globally (Espitia et al., 2021). The best economic outcome is likely to be a recession as deep as the economic outcome of the global financial crisis (GFC) of 2008-09. Following this, authorities worldwide spent an unprecedented amount of taxpayer money to bail out financial institutions with the aim of protecting the financial system. In response to the COVID-19, authorities are once again bailing out businesses, but the present bailout has a very different root cause than that of the GFC. The GFC was rooted in an overleveraged banking system that was overexposed to an also highly leveraged housing sector. The COVID-19 pandemic has caused widespread disruption to trade, with some businesses only operating at a fraction of their capability. Furthermore, economic agents are restraining economic activity and waiting to observe how the situation unfolds before making economic decisions. These behaviors cause an immediate shock to the economy on both the demand and supply sides. Since, as a result, many businesses are temporarily closed and workers are furloughed, governments must bail out businesses to ensure they will be able to resume activity after lockdowns are lifted.

Governments worldwide have implemented a number of measures to contain the spread of COVID-19 and ensure healthcare systems are able to cope (Hoekman et al., 2021). These include school and workplace closures, citywide and even nationwide lockdowns, and travel restrictions (Atkeson, 2020). These measures have proven effective across the world - the infection rate is declining, with most developed countries appearing to have passed the peak. Nevertheless, restrictions have far-reaching economic implications. Stock markets reacted to this environment, crashing across the globe as the future depressed earnings of companies were incorporated into forecasts. The link between the stock market and the economy has been well-established (Friend, 1972; Levine, 2005; Levine \& Zervos, 1998); however, the determinants of economic stimulus packages implemented in response to the COVID-19 crisis remains largely unanswered.

The economic stimulus packages implemented by governments worldwide are a combination of fiscal, monetary, and financial policy measures. Fiscal measures include paying furloughed employees' salaries and sick leaves, providing financial support for small and large businesses, government and the central banks financing facilities, and directly funding healthcare systems. Monetary policy measures include liquidity support for the financial sector and policy 
rate cuts (Beck, 2020). Other financial policy measures include guidance for banks and insurance companies on dividends and share buybacks (Shen, 2020).

We examine whether the stock market is a leading indicator of a country's stimulus package. This topic has been widely researched under the finance-growth nexus (Beck, Levine, \& Loayza, 2000; Levine, 2005; Levine \& Zervos, 1998), providing both theoretical and empirical evidence that financial markets boost economic growth. However, whether financial markets can predict an economic stimulus package in response to a crisis has never been studied to the best of our knowledge. The extent of a stock market decline indicates how investors view an economy's potential future performance. We, therefore, hypothesize that the greater the decline in a country's stock market index, the higher the economic stimulus package will be. Our study is motivated by the initial work of Elgin, Basbug, and Yalaman (2020), but we add several important determining factors to their model. Furthermore, we decompose economic stimulus packages (the CESI index) into their constituent monetary and fiscal components as well as the balance of payments/exchange rate measures. Earlier studies have highlighted the importance of stock market changes and the responsiveness of monetary authorities in adjusting interest rates (Bernanke \& Gertler, 1989, 2000; Bernanke, Gertler, \& Gilchrist, 1998). We found that a larger stock market decline leads to a larger economic stimulus package. However, this effect is only observed in developed and high-income countries with a per capita gross domestic product (GDP) greater than the median GDP per capita. This indicates that, in making their decisions, authorities should examine the stock markets of developed and high-income countries more closely, perhaps due to the presence of more well-developed financial markets. Moreover, we discover that authorities respond more aggressively to a stock market decline with monetary than fiscal policy. This indicates how important international donor agencies such as the World Bank and the IMF are in supporting less affluent countries in coping with the adverse impacts of COVID-19.

Our paper contributes to the existing literature in the following important ways. First, we address monetary and fiscal policy responses to changes in asset prices, exploring the financegrowth nexus in the wake of COVID-19. Specifically, we study the responsiveness of the COVID19 Economic Stimulus Index (CESI) to stock market declines. Second, we exploit recent volatility in stock market prices and examine whether monetary policy is more responsive compared to fiscal policy by decomposing the CESI into its constituent parts. Third, we contribute in terms of 
methodology since we apply quantile regression in addition to ordinary least squares (OLS) regression.

This paper is structured as follows. Section 2 reviews the existing literature, Section 3 derives the model applied for estimation and explains the data and empirical methodologies used, Section 4 presents results and relevant discussion, and finally, Section 5 provides concluding comments and policy implications.

\section{$2 \quad$ Literature Review}

The economic disruption caused by COVID-19 is unprecedented. To limit the spread of the disease, many countries resorted to complete or partial lockdowns of their economies. This adversely affected economic activity, leading to significant downward revisions of growth projections previously made by the IMF and others. The pandemic also resulted in significant global stock market volatility. For instance, volatility in US stock markets rivaled or surpassed those observed during the 2008-09 GFC or the October 1987 Black Monday crisis (Baker et al., 2020).

To mitigate the adverse impact of lockdown, governments introduced measures and relief packages including fiscal, monetary, and financial policy measures (Elgin et al., 2020). Using data from 166 countries, Elgin et al. created a measure that captured policy responses. Their results indicate responses are significantly associated with GDP per capita, median population age, number of hospital beds, and total COVID-19 cases. Similarly, Balajee, Tomar, and Udupa (2020) explored the impact of sovereign credit rating on fiscal responses. Their findings revealed countries with lower credit ratings are likely to provide lower fiscal stimulus. Moreover, countries with lower credit ratings tend to delay implementing fiscal stimulus.

Fukuda and Yamada (2011) explored the response of fiscal stimulus packages to "stock price targeting" in Japan. Their findings indicated targeting can reasonably predict Japan's fiscal expenditures and, in the absence of stock price targeting, the biannual fiscal stimulus in Japan would have been 2.5 trillion yen lower, on average, from 1992 to 2000. Tagkalakis (2012) investigated the relationship between volatility of different asset prices and volatility of fiscal policy. The findings provide evidence that an increase in asset price volatility also increases fiscal policy volatility. Primarily, volatility in the prices of equities and residential property also 
increases volatility in government revenues and spending (Tagkalakis, 2012). Moreover, trade openness results in larger variations in government revenue, government expenditures, and primary balance-to-GDP ratios. This is in line with the findings of Rodrik (1998), which suggested that to provide increased social insurance and reduce economic instability arising from a greater level of integration, countries more open to trade tend to have larger governments. Similarly, Kneller (2007) provided evidence that social insurance welfare spending is primarily affected by trade liberalization.

Few studies have explored the response of monetary policy to asset price volatility. Rigobon and Sack (2003) explored the magnitude of the US Federal Reserve's reaction. Their finding revealed that a rise (fall) in the Standard \& Poor's (S\&P) 500 index increased the likelihood of a tightening (easing) of US monetary policy. Similar findings were reported by Bjørnland and Leitemo (2009), indicating that a shock to the stock market that increased real stock prices by $1 \%$ resulted in an approximately four basis point increase in the interest rate. Earlier work by Bernanke and Gertler (1989, 2000) and Bernanke et al. (1998) also highlighted central bank responses to turmoil and asset price shocks, especially the stock market.

\section{3}

\section{Model, Data, and Methodology}

Our models are motivated by Elgin et al. (2020), who constructed the CESI, using principal component analysis (PCA), from seven policy variables measuring fiscal policy, monetary policy, and balance of payments/exchange rate policy. The source of these policy variables is the IMF's COVID-19 Policy Tracker, 2020. ${ }^{1}$ We specify a baseline model (1), in which the CESI is a function of a stock market fall and its interaction with the log of real GDP per capita, budget balance, log of the median age of the population, log of hospital beds per capita, and infection rate:

CESI

$$
\begin{aligned}
& =\beta_{1}(\text { Stock Fall } \times \ln \text { Real GDP Per Capita })+\beta_{2} \\
& (\text { Stock Rise } \times \ln \text { Real GDP Per Capita })+\beta_{3}(\text { Stock Fall })+\beta_{4}(\text { Stock Rise })+\beta_{5}( \\
& \text { Budget Balance })+\beta_{6}(\ln \text { Median Age })+\beta_{7}(\ln \text { Hospital Beds })+\beta_{8}( \\
& \text { Infection Rate })+\beta_{9}(\ln \text { Real GDP Per Capita })+\varepsilon
\end{aligned}
$$

${ }^{1}$ We used the fifth update (May 07, 2020) of the CESI by Elgin et al. (2020) to ensure that we were able to capture all economic stimulus packages that were offered since countries adopted strict public health measures such as restrictions on domestic movement, social gatherings, the operation of businesses and factories, and international travel. 
Here, stock fall is a dummy variable that represents a fall in the main stock market index of a particular economy in the wake of the COVID-19 pandemic - the beginning of 2020 to the first week of April - by more than one standard deviation (S.D.) (see Table 1 for S.D. of stock market change). It is defined below:

$$
(\text { Stock Fall })=\left\{\begin{array}{c}
1, \text { if }(\text { Stock Market Change })<-1 S . D . \\
0, \text { otherwise }
\end{array}\right.
$$

Data are obtained from various online sources, including Bloomberg and the respective country stock exchange websites. For some African countries for which stock market indices were unavailable, we used Bourse Régionale des Valeurs Mobilières (BRVM) and S\&P Africa 40 index. The BRVM is a regional stock exchange index serving west African countries, whereas the S\&P Africa 40 index is comprised of the 40 largest and most liquid companies operating in Africa. Similarly, we used the S\&P Latin America 40 index for some Latin American countries for which stock market indices were unavailable. Like stock fall, stock rise is a dummy variable that measures a stock market change of more than one S.D. It is defined as:

$$
(\text { Stock Rise })=\left\{\begin{array}{c}
1, \text { if }(\text { Stock Market Change })>+1 \text { S.D. } \\
0, \text { otherwise }
\end{array}\right.
$$

This approach to measuring changes beyond a particular threshold (such as one S.D.) is intuitive because we are interested in identifying substantial stock market falls attributable to the COVID-19 pandemic, overlooking day-to-day fluctuations. This approach has been widely used in the economics and finance literature, including in work by de Groot, Linders, and Rietveld (2005), Hameed, Kang, and Viswanathan (2010), and Kim, Shamsuddin, and Lim (2011).

We also incorporate interaction terms between the dummies, measuring stock market rises and falls beyond \pm 1 S.D. and the natural $\log$ of real GDP per capita. The intuition behind this is that how a government responds to stock market fluctuations depends on what it can afford and the economy's level of development prior to the pandemic. Interaction between the stock market and economic development has been widely used in the literature, including by Lyócsa (2014), Guo (2015), Pradhan, Arvin, and Ghoshray (2015). A more developed and/or higher-income economy will be able to provide a larger stimulus if there is a stock fall and vice versa. Such an 
economy is also expected to have a more developed and robust stock market, so a substantial fall is expected to trigger a government response.

Real per capita GDP, obtained from Elgin et al. (2020), is expressed in thousands of 2010 US dollars (US\$) and accounts for the economy's level of development. Real GDP per capita is expected to positively affect the CESI.

Budget balance controls a country's fiscal standing prior to the pandemic. We used the IMF's Fiscal Monitor Database's (October 2019 update) forecasted 2020 budget balances. We took this approach because the particular economy's fiscal standing prior to the pandemic should greatly determine its ability to mobilize economic stimulus in the wake of the pandemic.

The median age of a country's population is included since a higher-aged median voter is often expected to demand a larger stimulus package as well as welfare program (Bongaarts, 2004; Hollanders \& Koster, 2011). The COVID-19 pandemic has hit the elderly demographic particularly hard-with the vast majority of fatalities and serious illnesses following infection prevalent in the 60 years and above demographic (Ausubel, 2020; World Health Organization, 2020). This, in turn, is expected to strengthen demand for improved healthcare, income support, aged care, etc. However, an older population of voters is also prone to more conservative ideologies, including reduced government involvement in the economy, less transfer payments, bailouts etc. (Glenn, 1974; Peterson, Smith, \& Hibbing, 2020). As a result, the effect of the log of the median age on the COVID-19 economic stimulus package is ambiguous a priori.

We incorporate the log of the number of hospital beds per capita, which accounts for the capacity of the hospital system to cope with increased patient numbers during the pandemic. The greater the capacity to deal with increased patient numbers, the lower the likelihood is of a large stimulus package (Elgin et al., 2020). Infection rate measures the ratio of total positive cases to the population and is a proxy for the spread of the COVID-19 in the country in question. A high infection rate is expected to put more residents out of work, lower productivity, and burden the healthcare system, which, in turn, will shrink the economy. An impending recession —or one that is already entrenched - is expected to motivate a government to implement a big stimulus package. This was also the empirical observation by Elgin et al. (2020). 
In line with Elgin et al. (2020), the baseline model (1) is gradually augmented (one by one) with additional regressors such as the stringency index, the log of the total number of cases in the country, healthcare expenditures, real GDP growth rate, and the world uncertainty index for individual countries. This was done to determine the correct model specification and ensure that it adequately captures the prevailing state of the economy and other public health measures adopted by the particular economy, as well as avoid any omitted variable biases. The stringency index captures strict public health measures - such as restrictions on domestic movement, social gatherings, operation of businesses and factories, and international travel-undertaken by the government in the wake of the pandemic's onset. The stricter the public health measures, the more likely a larger stimulus to kickstart the economy once the restrictions are lifted. Data on the stringency index are sourced from the Elgin et al. (2020) dataset.

The total number of cases is a way to measure the size of the pandemic in a particular country. The higher the total number of cases, the more likely the government is to initiate a large stimulus package to overcome the decline in productivity and/or the loss of life. We take a log transformation of total cases to represent its diminishing marginal effect on the CESI.

Healthcare expenditure is measured as a percentage of GDP and accounts for the capability, sophistication, and robustness of the domestic healthcare system. The higher this is, the better equipped the system is to cope with COVID-19. In addition, higher healthcare expenditure is associated with welfare states that would be more inclined to offer larger stimulus packages to revitalize the economy (Castles, 2009). As such, the sign of the effect of healthcare expenditure on the CESI is ambiguous a priori, so the estimate will depend on the priorities of the relevant government and society-i.e., "cash versus services” (Bambra, 2005).

Lastly, other macroeconomic variables are added to the baseline model (1). GDP growth rate was forecast prior to the onset of the pandemic by the IMF's World Economic Outlook (October 2019 update). The intuition regarding the choice of this forecast (of real GDP growth rate) is the same as that of the budget balance. If an economy was expected to grow faster prior to the pandemic, the government would be more willing and able to afford a larger stimulus package (CESI). The world uncertainty index used for each country was obtained from the work of Ahir, Bloom, and Furceri (2018) and acts as a proxy for economic and political risk; a higher level of 
country risk/uncertainty, even before the pandemic, is expected to reduce the government's economic stimulus package (Auerbach \& Hassett, 2002; Hollmayr \& Matthes, 2015).

The fully specified model can be expressed as Equation (4):

CESI

$=\beta_{1}($ Stock Fall $\times \ln$ Real GDP Per Capita $)+\beta_{2}$

$($ Stock Rise $\times \ln$ Real GDP Per Capita $)+\beta_{3}($ Stock Fall $)+\beta_{4}($ Stock Rise $)+\beta_{5}($

Budget Balance $)+\beta_{6}(\ln$ Median Age $)+\beta_{7}(\ln$ Hospital Beds $)+\beta_{8}($

Infection Rate $)+\beta_{9}(\ln$ Real GDP Per Capita $)+\beta_{10}($ Stringency Index $)+\beta_{11}($

$\ln$ Total Cases $)+\beta_{12}$ (Health Expenditure $)+\beta_{13}($ Real GDP Growth Rate $)$

$+\beta_{14}($ World Uncertainty Index $)+\varepsilon$

These models ( $1 \& 4)$ were estimated using the OLS. They were also estimated without an intercept to avoid the dummy variable trap between the full set of stock fall and rise dummies and the intercept term. The list of countries included can be found in Table A1 in Appendix A. To verify the validity of the results, we perform diagnostic tests such as the Wald test for the joint significance of regressor coefficients (i.e., the $F$-test) as well as the Breusch and Pagan (1979)Godfrey (1978) test for heteroskedasticity.

OLS estimates the coefficients in the conditional mean. However, it overlooks the distributional aspect of the estimated relationship. For a particular coefficient, half of the observations may yield higher values, while the other half may yield lower values (Koenker \& Hallock, 2001). In other words, the model might exhibit a differing relationship between the regressors and regressands for different percentiles of the dataset. A quantile regression can be applied to capture distributional intricacies. ${ }^{2}$

\section{$4 \quad$ Empirical Results}

Table 1 provides summary statistics, divided using IMF's income classifications. The total number of observations of the variables ranges between 92 (world uncertainty index) to 113 (CESI, stock fall \& rise, stock market change, and budget balance). Preliminary evidence from the unconditional means suggests economic stimulus packages provided by high-income countries are, on average, larger than those introduced by low-income, lower-middle-income, and upper-

${ }^{2} \mathrm{~A}$ detailed discussion on the quantile regression method can be found in Appendix B.

This article is protected by copyright. All rights reserved 
middle-income countries; yet all three country groups experienced a similar stock market decline, with averages ranging from $-31.6 \%$ to $-32.7 \%$.

Total COVID-19 cases and infection rates are, on average, higher in high-income countries despite having a larger share of their GDPs dedicated to healthcare expenditures and a higher number of hospital beds per 1000 people. The median age is almost 17 years higher in highincome countries than low- and lower-middle-income countries, whereas the median age in uppermiddle-income countries is approximately nine years higher than that in low- and lower-middleincome countries.

In terms of economic variables, the average GDP per capita for high-income countries is approximately three times higher than that for upper-middle-income countries and almost 24 times higher than low-income and lower-middle-income countries. Real GDP growth for high-income countries is expected to be $-5.1 \%$ compared to $-3.8 \%$ for upper-middle-income countries and $0.5 \%$ for low-income and lower-middle-income countries. Lastly, in all three income groups, more than $80 \%$ of countries experienced a fall in stock prices, greater than one S.D. of the stock market change variable. In high-income countries, $93.8 \%$ of countries experienced a decline in the stock market that was greater than one S.D. of the stock market change variable.

Table 2 provides the OLS estimates. Column (1) reports estimated coefficients and standard errors from Model (1). The coefficients on the stock fall $\times \log$ of real GDP per capita interaction term, budget balance, infection rate, and log of real GDP per capita are all positive, while those of the stock rise $\times \log$ of real GDP per capita interaction term, stock fall, as well as the logs of median age and hospital beds are negative. However, only those of the stock fall $\times \log$ of real GDP per capita interaction term and infection rate, and the stock rise $\times \log$ of real GDP per capita interaction term and stock fall are significant. The stock rise dummy could not be included in the regressions due to near-perfect multicollinearity with the stock fall dummy.

The marginal effect of a stock market fall beyond -1 S.D. can be calculated using the following formula:

$$
\beta_{1} \times(\ln \text { Real GDP Per Capita })+\beta_{3}
$$

For example, if we consider Column (1) of Table 2, the marginal effect of stock fall will be equal to $(0.599 \times(\ln$ Real GDP Per Capita $)-5.170)$. Here, the value of the log of real GDP per 
capita is an important determinant of whether the marginal effect was positive or negative. For Model (1) estimates in Column (1), the marginal effect of a stock market fall is positive for both the mean (8.7) and the median (8.7) of the log of GDP per capita (see Figure 1.a). Thus, on average, a fall in the stock market beyond -1 S.D. results in governments of economies with real per capita incomes roughly US $\$ 6,100$ or higher embarking on a larger stimulus package. A similar stimulus impact of the infection rate can also be observed. Looking at the interaction term of the stock rise and the log of real GDP per capita, the marginal effect is always negative as the stock rise dummy is absent due to multicollinearity (implicit restriction of its zero effect on the CESI). A stock market rise beyond +1 S.D., thus, is found to reduce the government's economic stimulus response. These findings conform to the a priori expectations regarding their respective associations with the CESI. The adjusted R-squared value demonstrates that $48 \%$ of the variations in the CESI can be explained by the Model (1) estimates.

In Column (2), estimates from augmenting Equation (1) with the stringency index can be found. The positive coefficients on the stock fall $\times \log$ of real GDP per capita interaction term and budget balance are statistically significant and that of the stock rise $\times \log$ of real GDP per capita interaction term and stock fall negative and significant. The marginal effect of a stock market fall, computed using the mean and the median of the log of real GDP per capita, are now negative, with values of -0.4 and -0.5 , respectively (see Figure $1 . b$ ). However, these relatively low magnitudes indicate that as per capita income moves further above the mean and median, the marginal effect becomes positive. Thus, at a higher level of development, a stock market crash still increases the size of the economic stimulus. The marginal effect of a stock market rise is again negative and an improvement in the budget balance positive. The explanatory power (adjusted R-squared value) improves slightly to 0.68 . However, we lose more than half the observations when the stringency index is added. As a result, we follow Elgin et al. (2020) and proceed with estimating Model (1) without the stringency index. This also accommodates for any biases that might arise in the estimates due to small samples.

Model (1) is further augmented with the log of the total number of COVID-19 infections (log of total cases) and results reported in Column (3) of Table 2. The coefficients on the stock fall $\times \log$ of real GDP per capita and stock rise $\times \log$ of real GDP per capita interaction terms, as well as that of a stock fall, increase in value. The marginal effect is now positive at the mean and median values of the log of real GDP per capita (see Figure 1.c). The stock market rise is again 
found to reduce the CESI. The log of total cases increases the COVID-19 stimulus, which comes as no surprise. The explanatory power of the estimated model is now $50 \%$ of the variations in the CESI. The number of observations in Column (3) is on par with that of Column (1), Table 2.

Columns (4) to (6) further augment the specification with healthcare expenditure, real GDP growth rate, and world uncertainty index. Column (6) exhibits the full stimulus Model (4) without including the stringency index. The coefficients of the stock fall $\times \log$ of real GDP per capita and stock rise $\times \log$ of real GDP per capita interaction terms, as well as that of stock fall, decline in value slightly relative to their counterparts in Column (3). The marginal effects at the mean and median are negative but small in magnitude compared to Column (2) in all three specifications of Columns (4) to (6). As with Column (2), the marginal effects quickly become positive, with per capita income rising above the mean and median (see Figure 1.d to 1.f). Thus, we find robust evidence that, at higher-than-average levels of development/income, a stock market fall will motivate a government to increase the COVID-19 stimulus package.

In Column (6), we also find the log of median age to have a negative impact on the CESI. This is likely due to older voters favoring conservative economic policies (Glenn, 1974; Peterson et al., 2020). Moreover, the estimated results indicate healthcare expenditure and real GDP growth rate forecast prior to the pandemic are likely to increase the COVID-19 economic stimulus. The positive impact healthcare expenditure has on the CESI is reflective of the welfare considerations by the government when preparing the stimulus package as well as the preference for cash over services on average (Bambra, 2005; Castles, 2009).

The adjusted R-squared values improve slightly to $0.50,0.51$, and 0.52 , respectively, up from 0.50 in Column (3). The number of countries included in Columns (4) and (5) are about the same as Column (3), but in Column (6), it is substantially lower at 78. The vital statistics for all six estimated models in Columns (1) to (6) pass the $F$ - and homoskedasticity tests at the $1 \%$ and $5 \%$ levels of significance, respectively. As a result, the estimated findings from these specifications are consistent and efficient, so inferences made from them are valid and reliable.

As an added validation of our approach, we modified Equation (4) by removing the stock fall and rise dummies as well as their interaction terms with the log of real GDP per capita and replaced them with two variables: stock market change and its interaction term with the log of real GDP per capita. This is to ensure that our approach is not over-specified and that we are not 
overcounting the impact of a stock market change on the stimulus. The re-specified model can be represented by Equation (6), which does not include the stringency index to avoid the loss of more than half of the sample. ${ }^{3}$

\section{CESI}

$=\beta_{1}($ Stock Market Change $)+\beta_{2}$ (Stock Market Change $\times \ln$ Real GDP Per Capita $)$

$+\beta_{3}($ Budget Balance $)+\beta_{4}(\ln$ Median Age $)+\beta_{5}(\ln$ Hospital Beds $)+\beta_{6}($

Infection Rate $)+\beta_{7}(\ln$ Real GDP Per Capita $)+\beta_{8}(\ln$ Total Cases $)+\beta_{9}($

Health Expenditure $)+\beta_{10}($ Real GDP Growth Rate $)+\beta_{11}($

World Uncertainty Index) $+\varepsilon$

The estimated results can be found in Column (7) of Table 2. The coefficient of stock market change is positive and significant, while that of its interaction term with the log of real GDP per capita is negative but insignificant. The latter may be due to the asymmetrical interaction that stock market falls and rises have with the level of development in determining the COVID-19 stimulus. Overall, the marginal effect of a stock market change is positive - at and below the mean and median values of the log of real GDP per capita (see Figure 1.g) - in this specification, indicating an improvement in the stock market in the wake of the pandemic encourages larger government stimulus packages. This finding is counterintuitive. The explanatory power of the estimated Equation (6) is substantially lower, at $42.7 \%$, compared to its counterpart in Column (6) (Table 2). However, Equation (6) passes the tests for homoskedasticity and joint significance of its coefficients at the usual levels of significance. Nevertheless, Equation (6) estimates indicate that it fails to capture the asymmetries and intricacies of stock market falls and rises and their interaction with the level of development (i.e., the log of real GDP per capita), thus, validating our approach.

Table 3 provides the results from substituting each of the seven components of the CESI as the dependent variable in Equation (4). The coefficients on the stock fall $\times \log$ of real GDP per capita interaction term, as well as stock fall, are significant only in Column (3). The marginal effect of a stock fall on the reserve requirement and buffer - a monetary policy instrument - is positive at both the mean and median values of the log of GDP per capita, indicating that a stock fall is effective at encouraging expansionary monetary policy. In Column (5), the stock rise $\times \log$ of real GDP per capita interaction term is negative and significant, demonstrating that a stock rise discourages government from other types of expansionary monetary policy. The stock market is more effective in influencing monetary policy than fiscal or balance of payments measures

${ }^{3}$ Equation (6) does not feature an intercept to prevent the dummy variable trap.

This article is protected by copyright. All rights reserved 
because monetary policy is often highly responsive to movements in the stock market and vice versa (Basistha \& Kurov, 2008; Rigobon \& Sack, 2003). An interest rate cut is an effective and relatively easy expansionary monetary policy instrument, and stock market returns have been documented as responding considerably and swiftly to it ex post facto (Bernanke \& Gertler, 1989; Bjørnland \& Leitemo, 2009; Thorbecke, 1997). In contrast, an expansionary fiscal policy involves aggravating the debt burden of the government, while balance of payments measures involve timeconsuming and costly modifications to trade and exchange rate policies that can adversely affect the importation of vital medical and essential supplies (Evenett et al., 2021).

The log of median age is found to reduce fiscal policy packages (Column 1) but improve other monetary expansions (Column 5). This indicates that higher median age is associated with conservative economic policies that prefer monetary expansion over fiscal stimulus, bailouts, transfer payments, etc. The infection rate appears to increase fiscal packages (Column 1) but worsens other balance of payments measures (Column 7). An increase in the infection rate renders many in the labor force unproductive, requiring more substantial fiscal stimulus, bailouts, transfer payments. By contrast, it increases the import burden of medical and essential supplies, thereby discouraging the government from taking measures to improve their balance of payments. In a similar manner, the log of total cases has a negative impact on other balance of payments measures (Column 7). The level of development increases fiscal packages, indicating that governments in higher-income economies are more likely to implement larger fiscal expansions.

An increase in healthcare expenditure is also found to have a positive impact on fiscal policy packages (Column 1) but a negative impact on monetary expansions (Column 5) and other balance of payments measures (Column 7). The positive and negative effects of healthcare expenditure on fiscal packages and other monetary expansions represent the government's focus on improving the delivery of services (healthcare and otherwise) and the welfare of the general public, on average. An increase in healthcare expenditure involves easing the importation of critical medical supplies, thereby reducing the government's scope for implementing policies aimed at improving the balance of payments.

Looking at the vital statistics, we find the number of observations in all seven models is 78 . The adjusted R-squared values demonstrate explanatory powers between 94.6\% (Column 5) and $19.3 \%$ (Column 2) of the variations of their respective dependent variables. In Column (6), 
however, the adjusted R-squared value is negative, indicating that a horizontal line has better explanatory power than its estimates. The $F$-statistic rejects the null hypothesis of joint insignificance of the coefficients in six of the estimated models. The test for error variance finds the estimates from all seven columns to exhibit homoskedasticity. As such, except for Column (6), the estimates from Table 3 are unbiased and efficient, so valid inferences can be made. 
Table 4 reports results from the quantile regression analysis, excluding the stringency index. The regressions are estimated for a total of nine quantiles at regular 10-percentile intervals. The coefficient of the stock fall $\times \log$ of real GDP per capita interaction term is positive across all but statistically significant in five quantiles: at the $20^{\text {th }}, 40^{\text {th }}$, and between the $70^{\text {th }}$ and $90^{\text {th }}$ percentiles. In addition, stock fall is negative for all quantiles but significant in six: between the $20^{\text {th }}$ and $40^{\text {th }}$ and between the $70^{\text {th }}$ and $90^{\text {th }}$ percentiles. The marginal effect of a stock fall is negative in four quantiles: at the $20^{\text {th }}, 40^{\text {th }}$, and between the $70^{\text {th }}$ and $80^{\text {th }}$ percentiles. The magnitudes of these are smaller in the lower two quantiles than in the upper two. By contrast, the marginal effect of a stock fall is positive in the $90^{\text {th }}$ percentile, with values of some 0.78 and 0.77 at the mean and the median of the log of real GDP per capita, respectively, greater than the four negative marginal effects combined. The quantile estimates also corroborate the OLS finding that a stock fall motivates the government to undertake a larger stimulus package in higher-income and more developed economies.

The budget balance is seen to improve the CESI in one quantile - at the $60^{\text {th }}$ percentile — and is similar to that of Column (2) in Table 2. The coefficient of the log of the median age is negative in the lower eight quantiles and positive in the upper tail quantile. The negative coefficients in the lower tail quantiles - between the $20^{\text {th }}$ and $50^{\text {th }}$ percentiles - are statistically significant. This is similar to Columns (6) and (7) in Table 2. In the second-lowest quantile, the log of the total number of cases is also found to increase the size of the pandemic economic stimulus.

Like in Table 2, the coefficient of healthcare expenditure is positive in all nine quantiles but significant in only three: between the $20^{\text {th }}$ and $40^{\text {th }}$ percentiles. This indicates that increasing healthcare expenditure (as a share of GDP) increases the COVID-19 economic stimulus index in the lower tail of the distribution - especially in lower-income and developing countries. Finally, a higher economic growth forecast is found to increase the size of the COVID-19 economic stimulus in the lower six quantiles, indicating that higher economic and/or human development usually precludes the need for stimulus, bailouts, and other types of transfer programs.

In terms of the vital statistics, we find that the pseudo-R-squared value is low in the lower tail and that it increases as we move to the upper tail of the distribution. The explanatory power ranges from $27.8 \%$ in the $20^{\text {th }}$ percentile to $52.1 \%$ in the $90^{\text {th }}$ percentile. The bandwidths used in 
the quantile estimation process are low-between 0.081 and 0.227 - and demonstrate that the kernel density functions were not over smoothed, and that the data fit the distributions.

\section{$5 \quad$ Concluding Comments}

The COVID-19 pandemic continues to damage the global economy. To dilute its adverse economic impact, many countries worldwide have announced stimulus packages. Against this backdrop, this paper assesses the responsiveness of monetary and fiscal policy to dramatic changes in the stock market resulting from the pandemic. Our results indicate one of the driving factors for determining economic stimulus packages is stock market dips in response to COVID-19. However, this result is mainly driven by the level of development. Richer countries tend to respond more aggressively. In particular, we find the marginal effect of a stock fall on a stimulus package is positive and statistically significant for countries having incomes per capita higher than the mean/median income per capita. Moreover, we find the monetary policy to be relatively more responsive to a fall in stock prices compared to fiscal policy or balance of payments measures.

Our results demonstrate governments' responses are not only driven by the extent of the health shock but also the extent of the economic and financial shock. Asset markets and, specifically, stock markets react immediately to any negative or positive news regarding future economic activity. We provide evidence that governments around the world responded to a steep fall in their stock markets with stimulus packages. 
Data availability statement: Data sharing is not applicable to this article as no new data were created or analyzed in this study.

This article is protected by copyright. All rights reserved 


\section{References}

Ahir, H., Bloom, N., \& Furceri, D. (2018). The world uncertainty index (Publication no. SSRN 3275033).

Atilgan, E., Kilic, D., \& Ertugrul, H. M. (2017). The dynamic relationship between health expenditure and economic growth: Is the health-led growth hypothesis valid for Turkey? The European Journal of Health Economics: HEPAC: Health Economics in Prevention and Care, 18(5), 567-574. doi:10.1007/s10198-016-0810-5.

Atkeson, A. (2020). What Will Be the Economic Impact of COVID-19 in the US? Rough Estimates of Disease Scenarios. NBER Working Paper No. 26867. doi:10.3386/w26867. National Bureau of Economic Research.

Auerbach, A. J., \& Hassett, K. A. (2002). Fiscal policy and uncertainty. International Finance, 5(2), 229-249.

Ausubel, J. (2020). Populations skew older in some of the countries hit hard by COVID-19. Pew Research Center. https://www.pewresearch.org/fact-tank/2020/04/22/populations-skewolder-in-some-of-the-countries-hit-hard-by-covid-19.

Baker, S. R., Bloom, N., Davis, S. J., Kost, K. J., Sammon, M. C., \& Viratyosin, T. (2020). The Unprecedented Stock Market Impact of COVID-19 (0898-2937). Retrieved from.

Balajee, A., Tomar, S., \& Udupa, G. (2020). COVID-19, fiscal stimulus, and credit ratings. SSRN Electronic Journal.

Bambra, C. (2005). Cash versus services: 'Worlds of Welfare' and the Decommodification of Cash Benefits and Health Care Services. Journal of Social Policy, 34(2), 195-213.

Basistha, A., \& Kurov, A. (2008). Macroeconomic cycles and the stock market's reaction to monetary policy. Journal of Banking and Finance, 32(12), 2606-2616.

Beck, T. (2020). Finance in the times of coronavirus. In R. Baldwin \& B. W. d. Mauro (Eds.), Economics in the Time of COVID-19 (pp. 73-76). London, UK: CEPR Press.

Beck, T., Levine, R., \& Loayza, N. (2000). Finance and the sources of growth. Journal of Financial Economics, 58(1-2), 261-300.

Bernanke, B., \& Gertler, M. (1989). Agency costs, net worth, and business fluctuations. The American Economic Review, 79(1), 14-31. Retrieved from http://www.jstor.org/stable/1804770.

Bernanke, B., \& Gertler, M. (2000). Monetary Policy and Asset Price Volatility. National Bureau of Economic Research Working Paper Series, No. 7559. doi:10.3386/w7559. 
Bernanke, B., Gertler, M., \& Gilchrist, S. (1998). The Financial Accelerator in a Quantitative Business Cycle Framework. National Bureau of Economic Research Working Paper Series, No. 6455. doi:10.3386/w6455.

Bjørnland, H. C., \& Leitemo, K. (2009). Identifying the interdependence between US monetary policy and the stock market. Journal of Monetary Economics, 56(2), 275-282. doi:10.1016/j.jmoneco.2008.12.001.

Bongaarts, J. (2004). Population aging and the rising cost of public pensions. Population and Development Review, 30(1), 1-23.

Breusch, T. S., \& Pagan, A. R. (1979). A simple test for heteroscedasticity and random coefficient variation. Econometrica, 47(5), 1287-1294.

Castles, F. G. (2009). What welfare states do: A disaggregated expenditure approach. Journal of Social Policy, 38(1), 45-62.

de Groot, H. L. F., Linders, G.-J. M., \& Rietveld, P. (2005). INSTITUTIONS, GOVERNANCE and INTERNATIONAL TRADE. IATSS Research, 29(2), 22-29. doi:10.1016/S03861112(14)60130-8.

Elgin, C., Basbug, G., \& Yalaman, A. (2020). Economic policy responses to a pandemic: Developing the COVID-19 economic stimulus index. Covid Economics: Vetted and Real Time Papers (3), 40-54.

Espitia, A., Mattoo, A., Rocha, N., Ruta, M., \& Winkler, D. (2021). Pandemic Trade: Covid-19, Remote Work and Global Value Chains. The World Economy. doi: https://doi.org/10.1111/twec. 13117

Evenett, S., Fiorini, M., Fritz, J., Hoekman, B., Lukaszuk, P., Rocha, N., ... \& Shingal, A. (2021). Trade Policy Responses to the COVID-19 Pandemic Crisis. The World Economy. doi: https://doi.org/10.1111/twec.13119

Friend, I. (1972). The economic consequences of the stock market. The American Economic Review, 62(1/2), 212-219.

Fukuda, S.-i., \& Yamada, J. (2011). Stock price targeting and fiscal deficit in Japan: Why did the fiscal deficit increase during Japan's lost decades? Journal of the Japanese and International Economies, 25(4), 447-464. doi:10.1016/j.jjie.2011.10.001.

Glenn, N. D. (1974). Aging and conservatism. The Annals of the American Academy of Political and Social Science, 415(1), 176-186. Retrieved from http://www.jstor.org/stable/1041104. 
Godfrey, L. G. (1978). Testing for multiplicative heteroskedasticity. Journal of Econometrics, $8(2), 227-236$.

Guo, J. (2015). Causal relationship between stock returns and real economic growth in the preand post-crisis period: Evidence from China. Applied Economics, 47(1), 12-31. doi:10.1080/00036846.2014.959653.

Hameed, A., Kang, W., \& Viswanathan, S. (2010). Stock market declines and liquidity. The Journal of Finance, 65(1), 257-293.

Hoekman, B., Shingal, A., Eknath, V., \& Ereshchenko, V. (2021). COVID-19, public procurement regimes and trade policy. The World Economy. doi: https://doi.org/10.1111/twec.13118

Hollanders, D., \& Koster, F. (2011). The graying of the median voter aging and the politics of the welfare state in OECD countries. Netspar Discussion Paper No. 01/2011-003. SSRN Electronic Journal. doi:10.2139/ssrn.1754952.

Hollmayr, J., \& Matthes, C. (2015). Learning about fiscal policy and the effects of policy uncertainty. Journal of Economic Dynamics and Control, 59, 142-162. doi:10.1016/j.jedc.2015.08.002.

Kim, J. H., Shamsuddin, A., \& Lim, K.-P. (2011). Stock return predictability and the adaptive markets hypothesis: Evidence from century-long U.S. data. Journal of Empirical Finance, 18(5), 868-879. doi:10.1016/j.jempfin.2011.08.002.

Kneller, R. (2007). No miracles here: Trade policy, fiscal policy and economic growth. The Journal of Development Studies, 43(7), 1248-1269.

Koenker, R. (2005). Quantile Regression. Cambridge: Cambridge University Press.

Koenker, R., \& Hallock, K. F. (2001). Quantile regression. Journal of Economic Perspectives, 15(4), 143-156.

Levine, R. (2005). Chapter 12 Finance and growth: Theory and evidence. Handbook of Economic Growth, 1, 865-934.

Levine, R., \& Zervos, S. (1998). Stock markets, banks, and economic growth. American Economic Review, 537-558.

Lyócsa, Š. (2014). Growth-returns nexus: Evidence from three Central and Eastern European countries. Economic Modelling, 42, 343-355. doi:10.1016/j.econmod.2014.07.023.

Mauro, B. W. d. (2020). Macroeconomics of the flu. In R. Baldwin \& B. W. d. Mauro (Eds.), Economics in the Time of COVID-19 (pp. 31-35). London, UK: CEPR Press. 
Peterson, J. C., Smith, K. B., \& Hibbing, J. R. (2020). Do people really become more conservative as they age? The Journal of Politics, 82(2), 600-611. doi:10.1086/706889.

Piabuo, S. M., \& Tieguhong, J. C. (2017). Health expenditure and economic growth - A review of the literature and an analysis between the economic community for Central African states (CEMAC) and selected African countries. Health Economics Review, 7(1), 23. doi:10.1186/s13561-017-0159-1.

Pradhan, R. P., Arvin, M. B., \& Ghoshray, A. (2015). The dynamics of economic growth, oil prices, stock market depth, and other macroeconomic variables: Evidence from the G-20 countries. International Review of Financial Analysis, 39, 84-95. doi:10.1016/j.irfa.2015.03.006.

Rigobon, R., \& Sack, B. (2003). Measuring the reaction of monetary policy to the stock market. The Quarterly Journal of Economics, 118(2), 639-669.

Rodrik, D. (1998). Why do more open economies have bigger governments? Journal of Political Economy, 106(5), 997-1032.

Shen, S. (2020). Global survey of dividend policy during COVID-19. Global Risk Institute. Retrieved from https://globalriskinstitute.org/download/global-survey-of-dividend-policyduring-covid-19/.

Tagkalakis, A. (2012). Fiscal policy and asset price volatility. Empirica, 39(1), 123-156. doi:10.1007/s10663-011-9167-2.

Thorbecke, W. (1997). On stock market returns and monetary policy. The Journal of Finance, $52(2), 635-654$.

World Health Organization. (2020, April 02). Press briefing on COVID-19 and the health and well-being of older people [Press briefing]. Retrieved from https://www.facebook.com/WHOEurope/videos/163802871435665/ 
Table 1: Summary Statistics

\begin{tabular}{|c|c|c|c|}
\hline Variable & \multicolumn{2}{|l|}{ Middle Income } & High-Income \\
\hline Total cases & 136.324 & 3289.207 & 8177.732 \\
\hline & $(250.496)$ & $(15071.539)$ & $(20227.776)$ \\
\hline Median Age & 22.611 & 31.655 & 39.056 \\
\hline & $(4.976)$ & $(6.166)$ & $(6.405)$ \\
\hline Real GDP per capita (US\$, thousands) & 1563.283 & 7050.117 & 37855.566 \\
\hline & $(1021.355)$ & $(2426.008)$ & $(20876.411)$ \\
\hline Health expenditure ( $\%$ of GDP) & 5.504 & 6.446 & 7.675 \\
\hline & $(1.925)$ & $(2.400)$ & $(2.443)$ \\
\hline Hospital beds (per 1,000 people) & 1.069 & 3.521 & 4.383 \\
\hline & $(1.091)$ & $(2.295)$ & $(2.484)$ \\
\hline Infection rate $(\%)$ & $6.56 \mathrm{e}-06$ & 0.0000415 & 0.000517 \\
\hline & $(0.0000133)$ & $(0.0000487)$ & $(0.000749)$ \\
\hline Stock market change $(\%)$ & -0.327 & -0.316 & -0.326 \\
\hline & $(0.153)$ & $(0.164)$ & $(0.126)$ \\
\hline Budget balance ( $\%$ of GDP) & -2.089 & -2.685 & -2.984 \\
\hline & $(2.989)$ & $(8.780)$ & $(2.843)$ \\
\hline Real GDP growth rate ( $\%$; forecast $)$ & -0.518 & -3.819 & -5.138 \\
\hline & $(2.738)$ & $(2.818)$ & $(3.159)$ \\
\hline World uncertainty index (2019Q4) & 0.085 & 0.080 & 0.109 \\
\hline & $(0.086)$ & $(0.070)$ & $(0.082)$ \\
\hline CESI & -0.662 & -0.619 & 0.789 \\
\hline & $(0.526)$ & $(0.739)$ & $(1.409)$ \\
\hline Stock fall $(<-1$ S.D. $)$ & 0.833 & 0.828 & 0.938 \\
\hline & $(0.378)$ & $(0.384)$ & $(0.245)$ \\
\hline Stock rise ( $>+1$ S.D.) & 0.000 & 0.034 & 0.000 \\
\hline & $(0.000)$ & $(0.186)$ & $(0.000)$ \\
\hline Observations & 36 & 29 & 48 \\
\hline
\end{tabular}

Note:

Standard deviation in parentheses.

This article is protected by copyright. All rights reserved 




This article is protected by copyright. All rights reserved 
Table 2: Pandemic stimulus models, OLS estimates

Panel A: Regression estimates

Dependent variable: CESI

Independent variable

(1) (2)

(3)

(4)

(5)

(6)

(7)

Stock fall $(<-1$ S.D. $) \times$ Log of real GDP per capita

$0.599 * * *$

$0.512 * *$

$0.542 * * *$

$0.532 * * *$

$0.534 * * * \quad 0.511 * * *$

(US\$, thousands)

Stock rise $(>+1$ S.D. $) \times \log$ of real GDP per capita

$\begin{array}{llllll}(0.168) & (0.238) & (0.167) & (0.167) & (0.168) & (0.165)\end{array}$

(US\$, thousands)

Stock fall $(<-1$ S.D.)

$-0.221 * \quad-0.363 * * *$

$-0.247 * *$

-0.219 *

$-0.237^{*}$

$-0.252 * *$

$\begin{array}{cccccc}(0.121) & (0.113) & (0.119) & (0.120) & (0.121) & (0.115) \\ -5.170^{* * *} & -4.908^{* *} & -4.701 * * * & -4.653 * * * & -4.673 * * * & -4.542 * * * \\ (1.439) & (2.141) & (1.427) & (1.429) & (1.431) & (1.416) \\ - & - & - & - & - & -\end{array}$

Stock rise (>+1 S.D.)

Stock market change (\%)

Stock market change $(\%) \times$ Log of real GDP per

capita (US\$, thousands) 


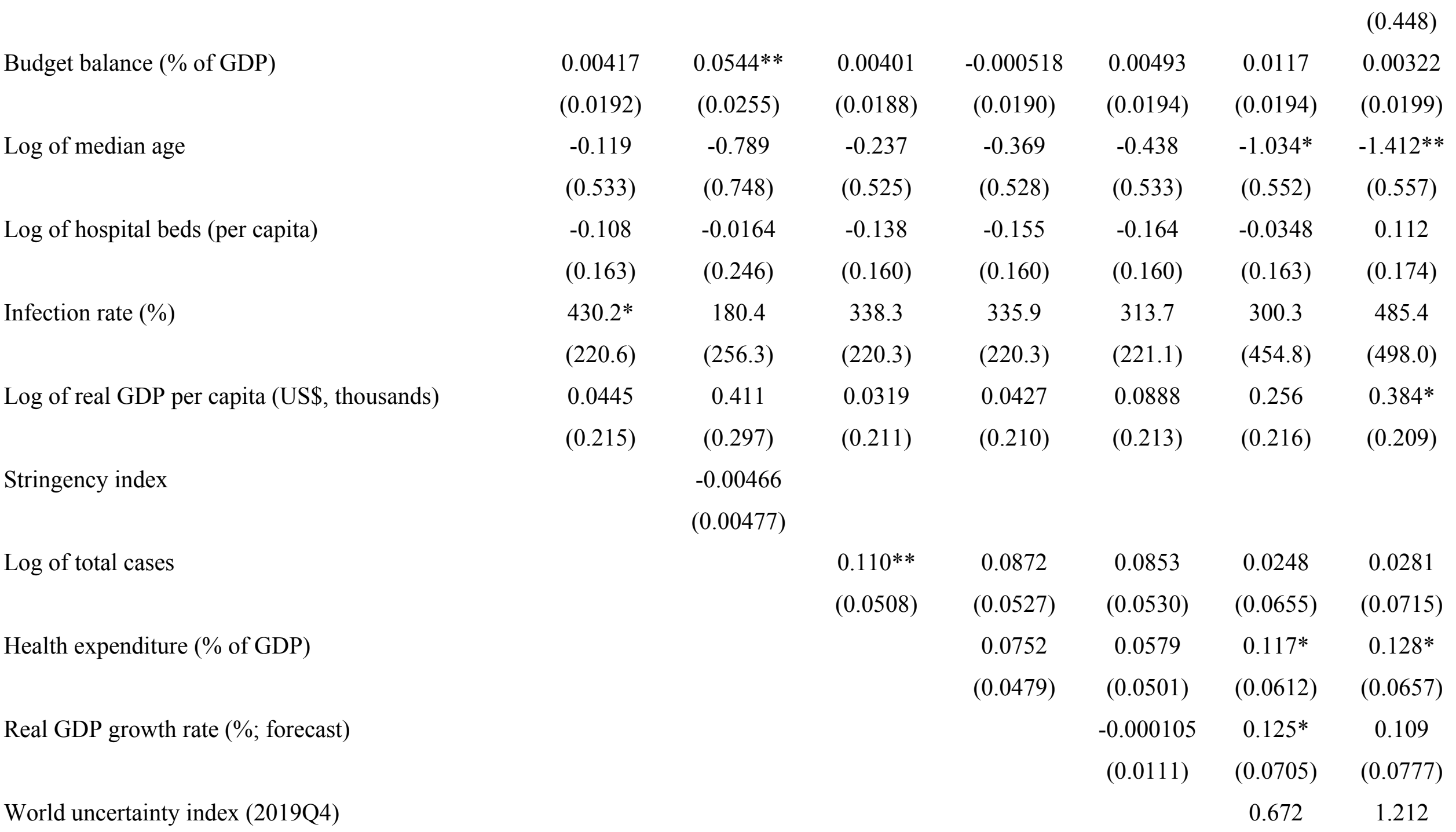




\section{Panel B: Model vital statistics}

\begin{tabular}{|c|c|c|c|c|c|c|c|}
\hline Observations & 96 & 43 & 96 & 95 & 94 & 78 & 78 \\
\hline Adjusted R-squared & 0.480 & 0.679 & 0.500 & 0.503 & 0.507 & 0.517 & 0.427 \\
\hline \multirow[t]{2}{*}{$F$-statistic a } & $12.060 * * *$ & $11.110 * * *$ & $11.680 * * *$ & $10.620 * * *$ & $9.770 * * *$ & $7.960 * * *$ & $6.280 * * *$ \\
\hline & $(0.000)$ & $(0.000)$ & $(0.000)$ & $(0.000)$ & $(0.000)$ & $(0.000)$ & $(0.000)$ \\
\hline \multirow[t]{2}{*}{ Homoskedasticity test $\mathrm{b}$} & 1.350 & 0.456 & 1.148 & 0.849 & 0.813 & 0.558 & 1.053 \\
\hline & $(0.230)$ & $(0.893)$ & $(0.339)$ & $(0.584)$ & $(0.627)$ & $(0.867)$ & $(0.413)$ \\
\hline
\end{tabular}

\section{Notes:}

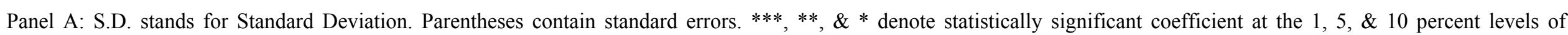
significance $(\alpha)$.

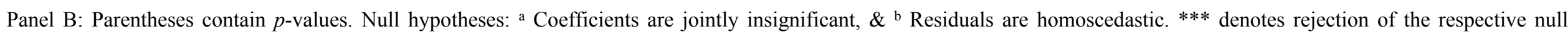
hypothesis at 1 percent level of significance. 
Table 3: Pandemic stimulus model estimates, disaggregating the CESI

\section{Panel A: Regression estimates}

\begin{tabular}{|c|c|c|c|c|c|c|c|}
\hline \multirow[b]{3}{*}{ Independent variable } & \multicolumn{7}{|c|}{ Dependent variable $=?$} \\
\hline & $\begin{array}{c}\text { Fiscal policy } \\
\text { package }\end{array}$ & $\begin{array}{l}\text { Interest } \\
\text { rate cut }\end{array}$ & $\begin{array}{l}\text { Reserve } \\
\text { requirement and } \\
\text { buffer }\end{array}$ & $\begin{array}{l}\text { Macro- } \\
\text { financial } \\
\text { package }\end{array}$ & $\begin{array}{l}\text { Other } \\
\text { monetary } \\
\text { policy }\end{array}$ & $\begin{array}{c}\text { B.o.P. } \\
\text { measures/GDP }\end{array}$ & $\begin{array}{c}\text { Other B.o.P. } \\
\text { measures }\end{array}$ \\
\hline & (1) & (2) & (3) & (4) & (5) & (6) & (7) \\
\hline \multirow{2}{*}{$\begin{array}{l}\text { Stock fall }(<-1 \text { S.D. }) \times \log \text { of } \\
\text { real GDP per capita (US\$, } \\
\text { thousands) }\end{array}$} & 0.510 & 2.039 & $15.22 * * *$ & 1.172 & -0.0214 & -0.0553 & -0.0438 \\
\hline & $(0.686)$ & $(5.346)$ & $(5.335)$ & $(0.814)$ & $(0.0437)$ & $(0.220)$ & $(0.0813)$ \\
\hline \multirow{2}{*}{$\begin{array}{l}\text { Stock rise }(>+1 \text { S.D. }) \times \text { Log of } \\
\text { real GDP per capita (US\$, } \\
\text { thousands) }\end{array}$} & -0.521 & -4.090 & -0.787 & -0.258 & $-0.119 * * *$ & -0.0273 & -0.0607 \\
\hline & $(0.477)$ & $(3.713)$ & $(3.705)$ & $(0.565)$ & $(0.0304)$ & $(0.153)$ & $(0.0565)$ \\
\hline \multirow[t]{2}{*}{ Stock fall (<-1 S.D.) } & -5.837 & -20.51 & $-126.9 * * *$ & -10.49 & 0.111 & 0.619 & 0.236 \\
\hline & $(5.874)$ & $(45.75)$ & $(45.65)$ & $(6.968)$ & $(0.374)$ & $(1.887)$ & $(0.696)$ \\
\hline
\end{tabular}

Stock rise (>+1 S.D.) 
Budget balance ( $\%$ of GDP)

Log of median age

Log of hospital beds (per capita)

Infection rate $(\%)$

I

Log of real GDP per capita (US\$,

thousands)

Log of total cases

$\begin{array}{ccc}(0.895) & (6.972) & (6.956) \\ -0.0842 & 1.554 & -2.116 \\ (0.272) & (2.118) & (2.114)\end{array}$

Health expenditure (\% of GDP)

$0.688 * * *$

0.00999

(0.254)

(1.976)

Real GDP growth rate (\%;

\begin{abstract}
0.468
\end{abstract}
0.677

(0.292)

(2.278)

$-5.300$

World uncertainty

index

$-7.269$

(2019Q4)

-0.234
$(0.626)$
3.596
$(17.79)$
-6.920
$(5.271)$
$-6,737$
$(14,665)$

0.0632
$(0.0956)$
-1.587
$(2.715)$
0.364
$(0.804)$

$-0.00124$

0.00247

$-0.00704$

1,377

(2,238)

(0.00513)

(0.0259)

$(0.00955)$

$0.295 * *$

(0.146)

$-0.0284$

0.425

(0.735)

(0.271)

$-0.0431$

0.114

$-0.00905$

(0.0432)

(0.218)

(0.0804)

$-359.4$

$-462.3 * *$

(606.2)

(223.6)

0.182

(120.2)

$-0.0120$

$-0.110$

1.365

(1.062)

(0.0570)

(0.288)

(0.106)

0.425

0.0226

(0.323)

(0.0173)

0.0477

(0.0874)

$0.0893 * * *$

0.363

$-0.0307 *$

$-0.00890$

(0.0322)

(1.972)

(0.301)

(0.0162)

(0.0815)

$-0.0537^{*}$

0.386

$-0.0173$

0.0152

(0.0301)

$-0.0311$

(2.273)

(0.347)

(0.0186)

(0.0939)

(0.0347)

52.30

5.358

0.0365

1.325

$-0.735$ 

$(5.216)$
(40.63)
(40.54)
(6.187)
$(0.332)$
$(1.676)$
$(0.618)$

\section{Panel B: Model vital statistics}

\begin{tabular}{|c|c|c|c|c|c|c|c|}
\hline Observations & 78 & 78 & 78 & 78 & 78 & 78 & 78 \\
\hline Adjusted R-squared & 0.667 & 0.193 & 0.353 & 0.463 & 0.946 & -0.053 & 0.352 \\
\hline \multirow[t]{2}{*}{$F$-statistic a } & $14.040 * * *$ & $2.560 * * *$ & $4.550 * * *$ & $6.600 * * *$ & $115.130 * * *$ & 0.670 & $4.530 * * *$ \\
\hline & $(0.000)$ & $(0.008)$ & $(0.000)$ & $(0.000)$ & $(0.000)$ & $(0.772)$ & $(0.000)$ \\
\hline \multirow[t]{2}{*}{ Homoskedasticity test $\mathrm{b}$} & 0.515 & 0.902 & 1.451 & 1.233 & 1.300 & 0.358 & 1.003 \\
\hline & $(0.897)$ & $(0.549)$ & $(0.166)$ & $(0.281)$ & $(0.240)$ & $(0.973)$ & $(0.456)$ \\
\hline
\end{tabular}

\section{Notes:}

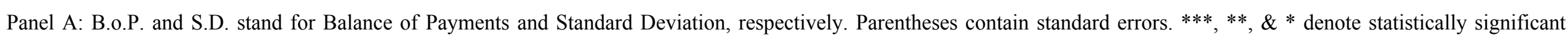
coefficient at the $1,5, \& 10$ percent levels of significance $(\alpha)$.

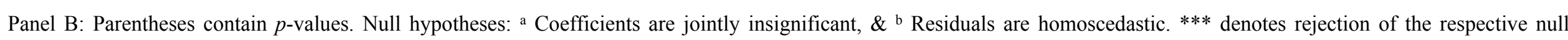
hypothesis at 1 percent level of significance.

This article is protected by copyright. All rights reserved 
Table 4: Pandemic stimulus model, quantile regression estimates

\begin{tabular}{|c|c|c|c|c|c|c|c|c|c|}
\hline \multicolumn{10}{|l|}{ Panel A: Regression estimates } \\
\hline \multirow[b]{4}{*}{ Independent variables } & \multicolumn{9}{|c|}{ Dependent variable: CESI } \\
\hline & \multicolumn{9}{|c|}{ Quantile, $(\tau)=?$} \\
\hline & 0.1 & 0.2 & 0.3 & 0.4 & 0.5 & 0.6 & 0.7 & 0.8 & 0.9 \\
\hline & (1) & (2) & (3) & (4) & (5) & (6) & (7) & (8) & (9) \\
\hline $\begin{array}{l}\text { Stock fall }(<-1 \text { S.D. }) \times \text { Log of real GDP per } \\
\text { capita (US\$, thousands) }\end{array}$ & $\begin{array}{c}0.383 \\
(0.287)\end{array}$ & $\begin{array}{l}0.404 * \\
(0.207)\end{array}$ & $\begin{array}{c}0.362 \\
(0.249)\end{array}$ & $\begin{array}{l}0.498^{*} \\
(0.282)\end{array}$ & $\begin{array}{c}0.400 \\
(0.293)\end{array}$ & $\begin{array}{l}0.411 \\
(0.279)\end{array}$ & $\begin{array}{l}0.481^{* *} \\
(0.228)\end{array}$ & $\begin{array}{c}0.832 * * * \\
(0.256)\end{array}$ & $\begin{array}{l}0.552^{* *} \\
(0.266)\end{array}$ \\
\hline $\begin{array}{l}\text { Stock rise }(>+1 \text { S.D.) } \times \text { Log of real GDP per } \\
\text { capita (US\$, thousands) }\end{array}$ & $\begin{array}{l}-0.133 \\
(0.121)\end{array}$ & $\begin{array}{c}-0.191 * * \\
(0.074)\end{array}$ & $\begin{array}{c}- \\
0.241 * * * \\
(0.087)\end{array}$ & $\begin{array}{l}-0.236^{* *} \\
(0.114)\end{array}$ & $\begin{array}{c}-0.247 * * \\
(0.120)\end{array}$ & $\begin{array}{c}- \\
0.329 * * * \\
(0.085)\end{array}$ & $\begin{array}{c}-0.316^{* * *} \\
(0.098)\end{array}$ & $\begin{array}{c}-0.324 * * \\
(0.128)\end{array}$ & $\begin{array}{l}-0.182 \\
(0.150)\end{array}$ \\
\hline Stock fall $(<-1$ S.D. $)$ & $\begin{array}{l}-3.252 \\
(2.113)\end{array}$ & $\begin{array}{l}-3.556^{* *} \\
(1.684)\end{array}$ & $\begin{array}{l}-3.380^{*} \\
(1.951)\end{array}$ & $\begin{array}{l}-4.413 * * \\
(2.279)\end{array}$ & $\begin{array}{l}-3.398 \\
(2.349)\end{array}$ & $\begin{array}{l}-3.768 \\
(2.343)\end{array}$ & $\begin{array}{c}-4.367 * * \\
(2.072)\end{array}$ & $\begin{array}{c}-7.598 * * * \\
(2.285)\end{array}$ & $\begin{array}{l}-4.038^{*} \\
(2.182)\end{array}$ \\
\hline Stock rise (>+1 S.D.) & - & - & - & - & - & - & - & - & - \\
\hline Budget balance (\% of GDP) & $\begin{array}{l}-0.021 \\
(0.022)\end{array}$ & $\begin{array}{c}0.006 \\
(0.015)\end{array}$ & $\begin{array}{c}0.011 \\
(0.015)\end{array}$ & $\begin{array}{c}0.013 \\
(0.019)\end{array}$ & $\begin{array}{c}0.021 \\
(0.020)\end{array}$ & $\begin{array}{l}0.033^{*} \\
(0.017)\end{array}$ & $\begin{array}{c}0.029 \\
(0.019)\end{array}$ & $\begin{array}{c}0.017 \\
(0.037)\end{array}$ & $\begin{array}{c}0.027 \\
(0.050)\end{array}$ \\
\hline Log of median age & $\begin{array}{l}-1.345 \\
(0.916)\end{array}$ & $\begin{array}{c}-1.442 * * \\
(0.690)\end{array}$ & $\begin{array}{c}-1.608 * * \\
(0.671)\end{array}$ & $\begin{array}{l}-1.381 * \\
(0.793)\end{array}$ & $\begin{array}{l}-1.401 * \\
(0.751)\end{array}$ & $\begin{array}{l}-1.162 \\
(0.727)\end{array}$ & $\begin{array}{l}-0.605 \\
(0.883)\end{array}$ & $\begin{array}{l}-0.044 \\
(1.059)\end{array}$ & $\begin{array}{c}0.328 \\
(0.926)\end{array}$ \\
\hline Log of hospital beds (per capita) & $\begin{array}{c}0.013 \\
(0.212)\end{array}$ & $\begin{array}{c}0.221 \\
(0.184)\end{array}$ & $\begin{array}{c}0.067 \\
(0.169)\end{array}$ & $\begin{array}{l}-0.040 \\
(0.191)\end{array}$ & $\begin{array}{c}0.026 \\
(0.203)\end{array}$ & $\begin{array}{c}0.031 \\
(0.197)\end{array}$ & $\begin{array}{c}0.015 \\
(0.217)\end{array}$ & $\begin{array}{l}-0.320 \\
(0.252)\end{array}$ & $\begin{array}{c}0.426 \\
(0.561)\end{array}$ \\
\hline
\end{tabular}

This article is protected by copyright. All rights reserved 


\begin{tabular}{|c|c|c|c|c|c|c|c|c|c|}
\hline Infection rate $(\%)$ & $\begin{array}{c}682.358 \\
(528.695)\end{array}$ & $\begin{array}{c}-93.260 \\
(358.741)\end{array}$ & $\begin{array}{c}10.730 \\
(359.640)\end{array}$ & $\begin{array}{c}139.169 \\
(499.643)\end{array}$ & $\begin{array}{c}318.565 \\
(643.437)\end{array}$ & $\begin{array}{c}163.420 \\
(710.964)\end{array}$ & $\begin{array}{c}1093.711 \\
(1214.369)\end{array}$ & $\begin{array}{c}893.193 \\
(1538.729)\end{array}$ & $\begin{array}{c}889.379 \\
(1993.305)\end{array}$ \\
\hline Log of real GDP per capita (US\$, thousands) & $\begin{array}{c}0.170 \\
(0.408)\end{array}$ & $\begin{array}{c}0.189 \\
(0.265)\end{array}$ & $\begin{array}{c}0.371 \\
(0.285)\end{array}$ & $\begin{array}{c}0.339 \\
(0.302)\end{array}$ & $\begin{array}{c}0.378 \\
(0.289)\end{array}$ & $\begin{array}{c}0.333 \\
(0.275)\end{array}$ & $\begin{array}{c}0.165 \\
(0.326)\end{array}$ & $\begin{array}{c}2.40 \mathrm{E}-05 \\
(0.360)\end{array}$ & $\begin{array}{l}-0.282 \\
(0.368)\end{array}$ \\
\hline Log of total cases & $\begin{array}{c}0.084 \\
(0.085)\end{array}$ & $\begin{array}{c}0.132 * * \\
(0.060)\end{array}$ & $\begin{array}{c}0.057 \\
(0.075)\end{array}$ & $\begin{array}{l}-0.004 \\
(0.088)\end{array}$ & $\begin{array}{l}-0.021 \\
(0.088)\end{array}$ & $\begin{array}{c}0.027 \\
(0.063)\end{array}$ & $\begin{array}{c}0.013 \\
(0.074)\end{array}$ & $\begin{array}{c}0.002 \\
(0.100)\end{array}$ & $\begin{array}{c}0.002 \\
(0.091)\end{array}$ \\
\hline Health expenditure ( $\%$ of GDP) & $\begin{array}{c}0.151 \\
(0.112)\end{array}$ & $\begin{array}{c}0.167 * * \\
(0.067)\end{array}$ & $\begin{array}{c}0.161 * * \\
(0.068)\end{array}$ & $\begin{array}{l}0.150^{*} \\
(0.081)\end{array}$ & $\begin{array}{c}0.130 \\
(0.081)\end{array}$ & $\begin{array}{c}0.083 \\
(0.070)\end{array}$ & $\begin{array}{c}0.079 \\
(0.084)\end{array}$ & $\begin{array}{c}0.155 \\
(0.100)\end{array}$ & $\begin{array}{c}0.136 \\
(0.123)\end{array}$ \\
\hline Real GDP growth rate (\%; forecast) & $\begin{array}{l}0.223^{*} \\
(0.132)\end{array}$ & $\begin{array}{l}0.211 * * \\
(0.088)\end{array}$ & $\begin{array}{c}0.187 * * \\
(0.076)\end{array}$ & $\begin{array}{l}0.182 * * \\
(0.081)\end{array}$ & $\begin{array}{l}0.164 * \\
(0.089)\end{array}$ & $\begin{array}{c}0.187^{* *} \\
(0.093)\end{array}$ & $\begin{array}{c}0.143 \\
(0.117)\end{array}$ & $\begin{array}{c}0.106 \\
(0.174)\end{array}$ & $\begin{array}{c}0.044 \\
(0.136)\end{array}$ \\
\hline World uncertainty index (2019Q4) & $\begin{array}{l}-2.918 \\
(2.637)\end{array}$ & $\begin{array}{c}0.489 \\
(1.543)\end{array}$ & $\begin{array}{c}0.293 \\
(1.971)\end{array}$ & $\begin{array}{c}0.973 \\
(1.484)\end{array}$ & $\begin{array}{c}0.991 \\
(1.566)\end{array}$ & $\begin{array}{c}0.874 \\
(1.397)\end{array}$ & $\begin{array}{l}-0.192 \\
(1.335)\end{array}$ & $\begin{array}{l}-1.172 \\
(1.784)\end{array}$ & $\begin{array}{c}4.231 \\
(5.561)\end{array}$ \\
\hline Panel B: Model vital statistics & & & & & & & & & \\
\hline Pseudo R-squared & 0.314 & 0.278 & 0.313 & 0.351 & 0.386 & 0.429 & 0.458 & 0.470 & 0.521 \\
\hline Bandwidth & 0.081 & 0.134 & 0.179 & 0.214 & 0.227 & 0.214 & 0.179 & 0.134 & 0.081 \\
\hline
\end{tabular}

Notes:

S.D. stands for Standard Deviation. Parentheses contain standard errors. ${ }^{* *}, * *, \& *$ denote statistically significant coefficient at the $1,5, \& 10$ percent levels of significance $(\alpha)$.

This article is protected by copyright. All rights reserved 
Figure 1: Marginal effect of Stock fall (<-1 S.D.) on CESI, OLS estimates (Table 2)

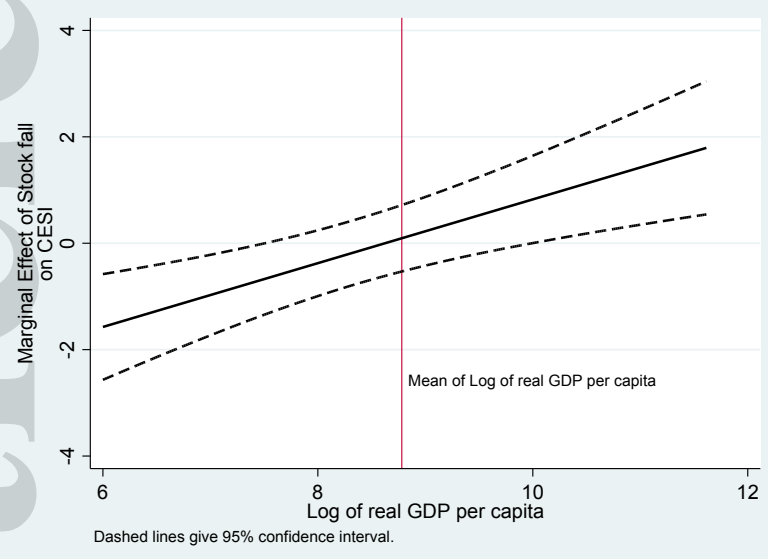

a. Column (1)

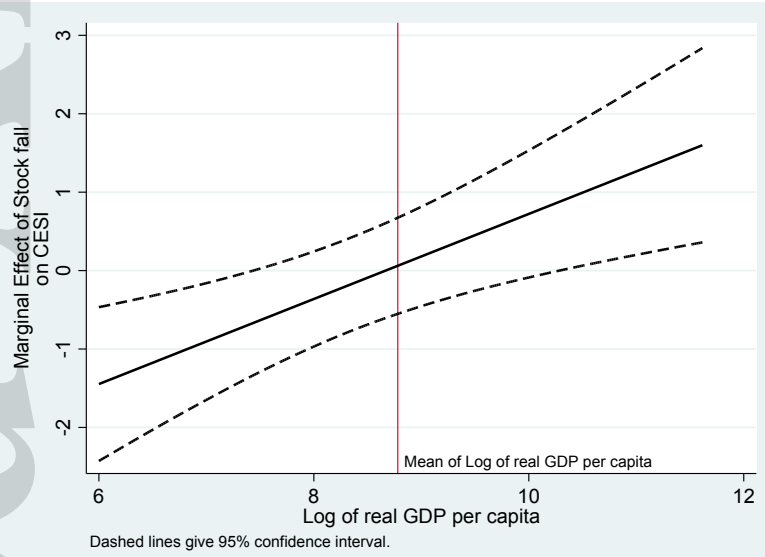

c. Column (3)

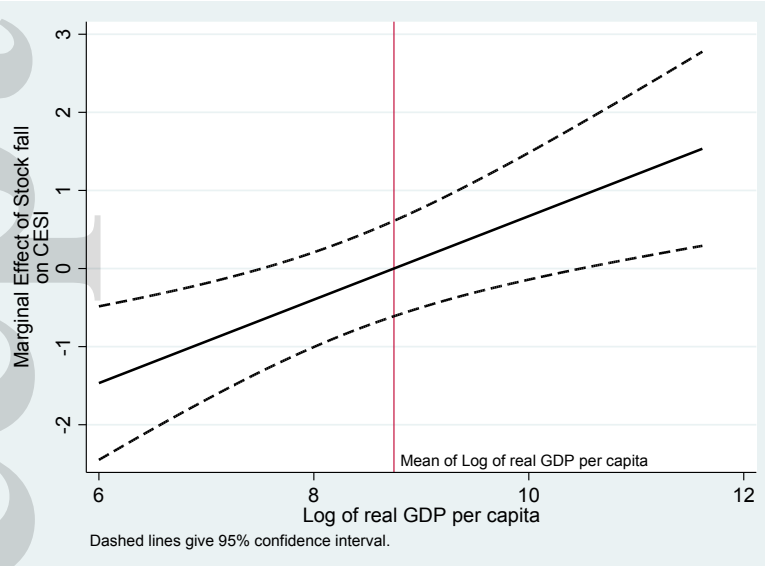

e. Column (5)



b. Column (2)

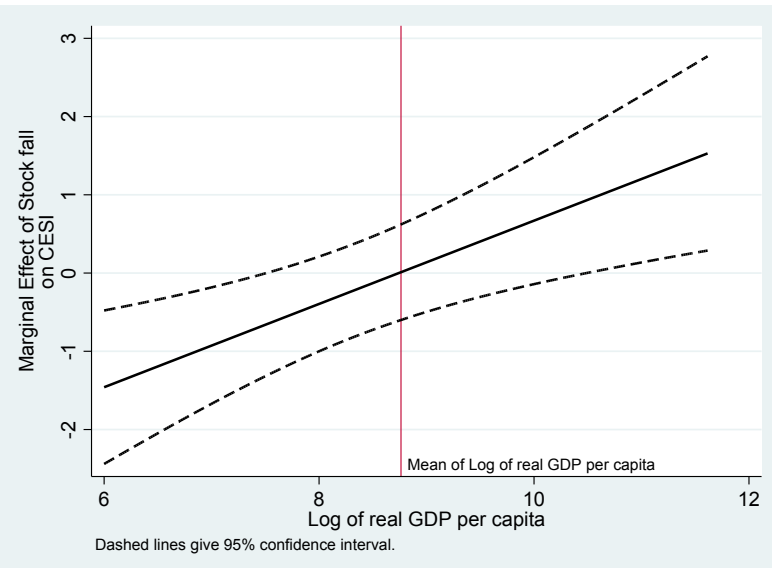

d. Column (4)



f. Column (6) 
Figure 1: Marginal effect of Stock fall (<-1 S.D.) on CESI, OLS estimates (Table 2)

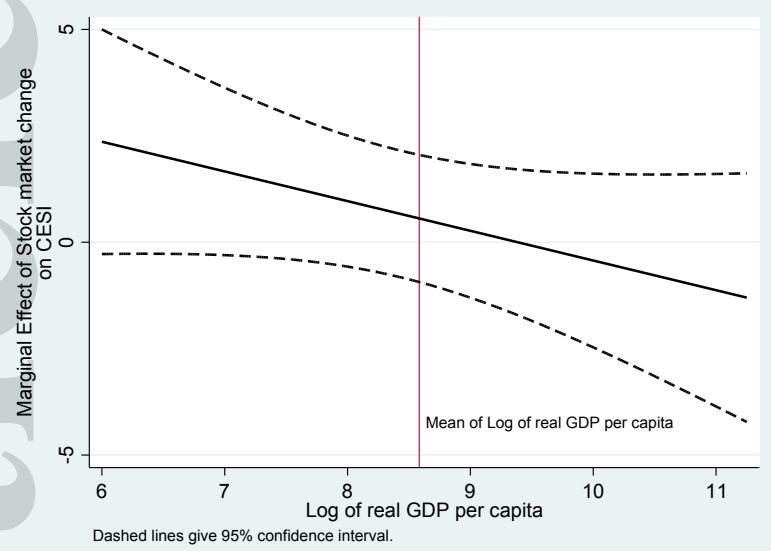

g. Column (7) \#

Note:

\# The coefficient estimate of the interaction term from Equation (6) is statistically insignificant. 
Table A1: List of countries in the dataset

\begin{tabular}{|c|c|c|c|}
\hline Algeria & Ethiopia & Malaysia & Slovenia \\
\hline Angola & Finland & Mali & South Africa \\
\hline Argentina & France & Malta & Spain \\
\hline Australia & Germany & Mexico & Sri Lanka \\
\hline Austria & Ghana & Moldova & Sudan \\
\hline Azerbaijan & Greece & Morocco & Sweden \\
\hline Bangladesh & Guinea & Mozambique & Switzerland \\
\hline Belarus & Haiti & Myanmar & Tajikistan \\
\hline Belgium & Honduras & Nepal & Tanzania \\
\hline Benin & Hong Kong & Netherlands & Thailand \\
\hline Brazil & Hungary & New Zealand & Timor-Leste \\
\hline Burkina Faso & Iceland & Nicaragua & Turkey \\
\hline Cambodia & India & Niger & Uganda \\
\hline Cameroon & Indonesia & Nigeria & Ukraine \\
\hline Canada & Iran & Norway & United Arab Emirates \\
\hline Chad & Ireland & Oman & United Kingdom \\
\hline Chile & Israel & Pakistan & United States \\
\hline China & Italy & Papua New Guinea & Uruguay \\
\hline Colombia & Japan & Peru & Uzbekistan \\
\hline \multicolumn{4}{|l|}{ Congo, Democratic } \\
\hline Republic of & Kazakhstan & Philippines & Vietnam \\
\hline Congo, Republic of & Kenya & Poland & Yemen \\
\hline Côte d'Ivoire & Korea, Republic of & Portugal & Zambia \\
\hline Croatia & Kuwait & Qatar & Zimbabwe \\
\hline Cyprus & Kyrgyzstan & Romania & \\
\hline Czech Republic & Laos & Russia & \\
\hline Denmark & Latvia & Rwanda & \\
\hline Dominican Republic & Libya & Saudi Arabia & \\
\hline Ecuador & Lithuania & Senegal & \\
\hline
\end{tabular}




\begin{tabular}{lll}
\hline Egypt & Luxembourg & Singapore \\
Estonia & Madagascar & Slovak Republic \\
\hline
\end{tabular}

This article is protected by copyright. All rights reserved 


\section{Appendix B: Quantile Regression Method}

Following Koenker (2005), we explain the concept of a quantile by considering a random variable $X$ that has real values for the which the (right-continuous) distribution function is expressed as:

$$
F(x)=P(X \leq x)
$$

where, satisfying the bounds $0<\tau<1$, Equation (B2) is defined as the $\tau$ th quantile of $X$.

$$
F^{-1}(\tau)=\inf \{x: F(x) \geq \tau\}
$$

For an empirical implementation on a dataset of $n$ observations, the distribution function $F$ is replaced by Equation (B3),

$$
F_{n}(x)=n^{-1} \sum_{i=1}^{n} I\left(X_{i} \leq x\right)
$$

Here, the indicator function, $I$, takes the value of one (1) if a particular argument (defined arbitrarily by the researcher) is true and zero (0) otherwise. The empirical interval of solutions for $\tau$ th quantile of $X$ is given as:

$$
F_{n}^{-1}(\tau)=\inf \left\{x: F_{n}(x) \geq \tau\right\}
$$

This yields the optimization problem as Equation (B5):

$$
\begin{gathered}
F_{n}^{-1}(\tau)=\operatorname{argmin}_{\xi}\left\{\sum_{i: X_{i} \geq \xi} \tau\left|X_{i}-\xi\right|+\sum_{i: X_{i}<\xi}(1-\tau)\left|X_{i}-\xi\right|\right\} \\
=\operatorname{argmin}_{\xi}\left\{\sum_{i} \rho_{\tau}\left(X_{i}-\xi\right)\right\}
\end{gathered}
$$

where, $\xi \in \mathbf{R}$ and $\rho_{\tau}(u)$ represent the piecewise linear loss function that puts asymmetric weight on negative and positive values of the disturbance term, $u$, 


$$
\rho_{\tau}(u)=u(\tau-I(u<0))
$$

The solution to the optimization problem in Equation (B5) is the quantile of $X$. This solution can be applied to a general procedure regressing conditional quantile functions. Consider $y$ as a function of vector $z$ containing $p$ number of regressors. The conditional quantile function for the $\tau$ th quantile under a regression framework is given by:

$$
Q_{y}(\tau \mid z)=z_{i}^{\top} \beta(\tau)
$$

Estimating the empirical quantile regression requires solving (minimizing) the unconditional quantile Equation (B8),

$$
\hat{\beta}_{n}(\tau)=\underset{\beta \in \mathbb{R}^{p}}{\operatorname{argmin}}\left\{\sum_{i=1}^{n} \rho_{\tau}\left(y_{i}-z_{i}^{\top} \beta(\tau)\right)\right\}
$$

This generates $\hat{\beta}(\tau)$, which is a vector of $p$ number of estimated coefficients for the $\tau$ th conditional quantile. 